\title{
ELECTRONIC COMMERCE AND MARKET FOCUS: SOME FINDINGS FROM A STUDY OF SWEDISH SMALL TO MEDIUM ENTERPRISES
}

\author{
Lejla Vrazalic \\ Department of IS, University of Wollongong, Wollongong 2500, Australia \\ $\mathrm{Ph}(612) 42213750$ Fax (61 2) 42214474 \\ lejla@uow.edu.au \\ Deborah J Bunker \\ School of IS, Technology and Management, University of New South Wales, Sydney 2052, Australia \\ $\mathrm{Ph}(612) 93854255$ Fax (61 2) 96624061 \\ d.bunker@unsw.edu.au \\ Robert C MacGregor \\ Department of IS, University of Wollongong, Wollongong 2500, Australia \\ $\mathrm{Ph}(612) 42213758$ Fax (61 2) 42214474 \\ robert_macgregor@uow.edu.au \\ Sten Carlsson \\ Department of IS, Karlstad University, SE-651 88 Karlstad, Sweden \\ $\mathrm{Ph}$ (46 54) 7001135 Fax (46 54) 7001446 \\ Sten.Carlsson@kau.se \\ Monika Magnusson \\ Department of IS, Karlstad University, SE-651 88 Karlstad, Sweden \\ $\mathrm{Ph}(46$ 54) 7002170 \\ Monika.Magnusson@kau.se
}

\begin{abstract}
In the past, organisations relied on traditional quantitative metrics, such as return on investment (ROI) to make decisions when investing in technology. With the advent of electronic commerce (EC), these decisions are becoming less reliant on ROI measures. Instead different driving forces are taking precedence in the decision making process. This paper presents the findings of a study of 118 Swedish small to medium enterprises (SMEs) that have adopted EC. The results of the study suggest that improvements to customer service, internal efficiency and organisational competitiveness have become equally important when making EC investment decisions. The study also examined whether major market focus (local, regional, national or international) had an influence on the organisation's decision to adopt EC. Findings indicate no associations between the market focus and the driving forces, however the existence of a fully developed plan for EC adoption and the size of the business were found to be highly associated with the development of new markets as an EC adoption criteria.
\end{abstract}

\section{INTRODUCTION}

Electronic commerce (EC) has led to changes in the day-to-day procedures of organisations (Kuljis et al, 1998). Technology is no longer viewed as a set of stand alone systems, but has become fully integrated with the overall organisational strategy (Turban et al, 2000; Raisch, 2001; Porter, 2001; Rajkumar, 2001). Organisations that have adopted EC or are in the process of considering this type of information technology (IT) investment, have found that traditional return on investment (ROI) calculation methods are not sufficient for the purpose of accurately measuring IT payback (Moozakis \& Lewis, 2000; Lewis, 2000a; Violino, 2000b). This has led organisations to use alternative evaluation methods and different sets of organisational criteria against which to measure investments in IT. This is particularly relevant to the small to medium enterprise (SME) sector where changes brought about by the advent of EC are having a significant impact.

This paper begins by briefly examining some of the changes brought about by the advent of EC, in particular changes to the metrics used by organisations when considering investment in EC technology. This is followed by a discussion of the nature and internationalisation of SMEs, in particular their approach to the acquisition, investment and use of EC technology. The paper then presents a study of 118 Swedish SMEs which investigated the major reasons behind their adoption of EC. The study also examines whether the respondent SMEs' major market focus (local, regional, national or international) influenced their decision making in the EC adoption process. Finally, the study endeavours to ascertain whether factors such as the size of the business or the existence of a fully developed plan for the acquisition of EC are associated with the importance of reaching new markets as a criterion for EC adoption. 


\section{EC TECHNOLOGY DECISION MAKING PROCESSES}

Organisations have encountered different problems in attempting to formally measure the adoption and profitability of IT investments in EC. A number of authors (Kollman, 1998; Dugan, 1999; Hlava, 1999; Wilder, 1999; Violino, 2000a; Cameron, 2000) have argued that with the advent of EC, traditional measurements have become obsolete or invalid. Some of the problems associated with traditional metrics include the inability of accounting for hidden costs and intangible strategic benefits of EC and the necessity of constantly revising evaluation methods in line with the fast pace of IT developments. Conventional ROI calculations fail to alleviate these problems. Moozakis and Lewis (2000) argue that this is due to the lack of product tangibility and an increase in virtual organisational structures. These developments are in direct contrast to the formal, material nature of ROI measurements.

There have been diverse attempts to apply different forms of evaluation methods and calculations in order to gauge the payback of IT investments. Indeed, Wilder (1999:48) reports that many organisations are "tossing out conventional thinking about the need for a return on investment and focusing on how the initiatives advance their overall business strategy, whether it's to improve customer satisfaction, increase brand awareness, or open new sales channels". Organisations have begun to rely on in-house, as well as off-the-shelf products for this purpose (Moozakis \& Lewis, 2000). Some of the evaluation criteria used by organisations include improvement in lead time (Riemenschneider \& Mykytyn, 2000), development of new markets (Wilder, 1999), improved relationships with business partners (Korchak \& Rodman, 2001) and improved marketing (Cameron, 2000). The methods employed range from: identifying sources of sales revenue generated through and attributable to EC and customer satisfaction surveys (Violino, 2000a; 2000b); measuring the IT performance of an EC website as a whole; operational cost savings, observing customers' surfing and online purchasing habits to expand marketing strategies; determining the revenues generated during off-business hours; counting online transactions and the number of online visitors (Lewis, 2000); as well as benchmarking against competitors. Where these methods fail, they are replaced by the instincts and experience of managers and decision makers (Violino, 2000a). Not surprisingly, some organisations (specifically large businesses) have begun viewing EC outlays as absolutely necessary, regardless of cost, in order to remain competitive (Quinn, 2000). Cameron (2000) further confirms the abandonment of formal ROI calculations by stating that IT projects and investments can be justified for any number of reasons, without ever measuring any form of ROI, thus highlighting the importance placed on EC in the modern organisation. Evans (2001) argues, however, that before EC can achieve any impact it must first be fully aligned and integrated with the overall strategy of the business. Indeed, Brynjolfsson and Hitt (1998) assert that EC cannot exist without investment in organisational change. The study presented in this paper has focused on SMEs, therefore it is now appropriate to examine the nature and internationalisation of SMEs, in particular their acquisition and use of IT and EC technology.

\section{THE NATURE OF SMALL BUSINESS}

The special circumstances of small business have been the topic of many government committee findings as well as research initiatives. Barnett and Mackness (1983) suggest that small businesses should not be thought of as miniature versions of large businesses, but quite unique in their own right. Small business tends to be more risky than its larger counterpart (Brigham \& Smith 1967; Walker 1975), it is subject to higher failure rates (Klatt 1973; Cochran 1981) and tends to keep less adequate records (Markland 1974; Rotch 1987).

Reynolds et al (1994) provide the following summary of features of small business generally not shared by larger organisations: a small management team; strong owner influence; multi-functional management; a close and loyal work team; centralised power and control; lack of specialist staff; informal and inadequate planning and control systems; lack of promotable staff; lack of control over the business environment; limited ability to obtain finance; labour intensive work; limited process and product technology; narrow product/service range, limited market share and heavy reliance on few customers; intuitive rather than rational decisions; reactive rather than innovative responses to change; personal rather than tasks oriented leadership; practical but narrow education, experience and skills; low employee turnover; product dedication rather than customer orientation; reluctance to take risks; management heavily swayed by the owner's personal idiosyncrasies; strong desire for independence; and intrusion of family interests.

In line with general views concerning small business, the acquisition and subsequent use of computer technology in the small business environment cannot simply be considered a miniaturised version of the larger organisation. Clearly, many of the features gleaned from studies of larger businesses can be applied to small business. However, the nature of small business operations presents a variety of factors which must be considered when computer technology is acquired in the small business environment. Increasingly, the acquisition of EC technology in particular has also meant increased global exposure for SMEs. This trend will be briefly discussed in the next section. 


\section{INTERNATIONALISATION OF SMES}

It is now widely acknowledged that the Internet has changed the way SMEs do business by revolutionising the dynamics of international commerce and enabling cross-border information flows and transactions (Quelch \& Klein, 1996). One of the main uses of the Internet has been for globalisation, allowing SMEs to achieve rapid growth and internationalisation (Ellsworth and Ellsworth, 1997). The creation of global markets and the advent of EC have brought about a new set of opportunities and challenges to SMEs (Raymond, 2000; Nielson \& Morris, 2001; Quelch \& Klein, 1996). Quelch and Klein (1996) argue that the Internet will cause a reduction in global advertising costs and increase advertising efficiency, erode the competitive advantages of scale economies, decrease information dissemination and communication costs by abolishing geographical and temporal barriers, thus, allowing SMEs to reach a critical mass of customers. In order to achieve this low cost access to global markets and customers, SMEs have had to invest in and acquire EC. It is now appropriate to examine EC acquisition by SMEs, in particular the criteria used by SMEs for EC adoption, as well as the effect, if any, of potential globalisation.

\section{ACQUISITION OF IT AND EC BY SMES}

There have been many studies, over the years, investigating the acquisition and use of both IT and EC by SMEs. These studies have often been directed towards trying to determine the IT success in SMEs. In the past, many of the studies tended to be directed towards specific sectors of the SME: users, vendors and management (see Schultz et al, 1984; McDoniel et al, 1993). User-oriented issues included perceptions and expectations of IT, user involvement, acceptance and training. Investigators have studied the impact of users' beliefs and attitudes on their usage behaviour (Robey, 1987; Ginzberg, 1982; Ives et al, 1983), and how these internal beliefs and attitudes are, in turn, influenced by various external factors. These factors include the system's technical design characteristics (Gould et al, 1983 and Dickson, Desanctis \& McBride, 1986 cited in Ditsa, 1994); user involvement in system development (Baroudi et al 1986; Tait \& Vessey, 1988; Amoako-Gyampah \& White, 1993; Burton et al, 1993); the type of system development methodology used (Alavi, 1984); the nature of the implementation process (Ginzberg, 1978); and cognitive style (Szajna \& Scamell, 1993). On the other hand, 'vendor' studies have concluded that ongoing success with IT was positively associated with vendor support, vendor after sales service, vendor training and vendor expertise (see Yap et al, 1992; MacGregor \& Cocks, 1995; MacGregor et al, 1995). Finally, management involvement in the acquisition of IT by SMEs has been reported by Bergeron et al (1990), Jarvenpaa and Ives (1991), and Fink and Tjarka (1994). More recently, however, studies surrounding the adoption of both IT and EC (see MacGregor \& Bunker, 1996a; ibid 1996b; Thong, 1999, Bunker \& MacGregor, 2000; Mirchandani \& Motwani, 2001) have suggested the need to look at the driving forces or criteria behind EC adoption in relation to the overall strategy of the SME rather than simply relating the driving forces to specific sectors.

In a study of 308 CEO's, Riemensheneider and Mykytyn (2000) nominated a variety of reasons, which they termed 'Most Important Things' that prompted SMEs into the adoption of EC. These included reduction of costs, increased productivity, faster feedback of information and access to customers. A similar study of the Asia Pacific region by Price Waterhouse Coopers (1999), as well as studies by Fuller (2000) and Kendall (2000) suggested factors such as improved customer service, customer information exchange, improved competitiveness, increased revenue, attracting new investment and access to international markets as reasons put forward by SMEs for their adoption of EC. Access to new markets and global customers has, in fact, been singled out by various authors as one of the most important driving forces behind EC adoption and use by SMEs.

A National Small Business United and Arthur Andersen survey of SMEs in 1997 indicated that 86.7\% of the respondents that had a website used it to reach new customers, while $30.4 \%$ had a website to support global expansion. In 1996, the same survey reported that only $8 \%$ of the respondents had home pages on the Web and more than $77 \%$ did not use the Internet to conduct business. Clearly, claims that EC is changing the way SMEs view globalisation and competition (Poon 2000) are legitimate. In fact, the same survey in 1998 reported that SMEs viewed the Internet as their most favoured growth strategy in the next 12 months.

Adopting EC and developing an online strategy has enabled SMEs to expand their customer base globally (Tetteh \& Burn, 2001; Maloff, 1995) and reach markets and customers that were once unreachable (Shewmake \& Sapp, 2000; Bennett, 1997) allowing SMEs to compete locally, nationally and internationally. Quelch and Kelin (1996) argue that EC will lead to rapid internationalisation of SMEs. It has also been argued that the Internet might decrease export barriers faced by SMEs (Bennett, 1997; Hamill, 1997). Bennett (1997:327) argues that “... the use of the Internet for global marketing enables firms to leapfrog the conventional stages of internationalisation, as it removes all geographical constraints, permits the instant establishment of virtual branches throughout the world, and allows direct and immediate foreign market entry to the smallest of 
businesses". Finally, a study by Poon and Swatman (1997) suggests that SMEs believe it is cheaper to compete globally through the Internet. The implications of this are significant.

A research study of Swedish SMEs which aimed to investigate the relationship between organisational factors and driving forces or criteria for EC adoption by SMEs will now be described. The study also examined whether the major market focus of SMEs (local, regional, national or international) was associated with any of these driving forces.

\section{SURVEY INSTRUMENT}

A questionnaire was developed for SME managers. A series of factors termed 'driving forces for the adoption of EC' were developed. The inclusion and exclusion of factors was based on previous studies, in particular those carried out by Price Waterhouse Coopers (1999) and Riemenschneider and Mykytyn (2000). Only those factors which were reported as having a greater than $50 \%$ response as important were included in the survey instrument. The factors included in the questionnaire were: customer demand, pressure by competition, pressure by suppliers, reduced cost, improvements to customer services, improvements to lead time, increased sales, improvements to internal efficiency, improved relationships with business partners, development of new markets, improved organisational competitiveness, improved marketing and improved internal control of the business.

Respondents were asked to rate each of these factors as pertaining to their adoption of EC across a 5 point Lickert scale where 1 indicates that the factor was unimportant to the decision to adopt EC, 2 indicates little importance to the decision to adopt EC, 3 indicates some importance to the decision to adopt EC, 4 indicates the factor was quite important to the decision to adopt EC and 5 indicates it was of greatest importance to the decision to adopt EC. Respondents were also asked about their market focus (local, regional, national or international), whether a full enterprise wide plan had been developed and documented for the use of EC within the organisation and the size of the business (sole entrepreneur, 1-9, 10-19, 20-49, >50). Questionnaires were distributed to SMEs around the four regional areas of Sweden: Karlstad, Filipstad, Saffle and Arvika.

\section{ANALYSIS OF RESPONSES}

\section{i) Overview of responses}

A total of 1170 questionnaires were distributed. Responses were obtained from 260 SME organisations giving a response rate of $22.2 \%$. This response rate was considered to be acceptable for the purposes of this study, however, further analysis indicated that of the 260 responses, only118 stated that they were using EC in their day-to-day business activities. These figures highlight that as little at $10 \%$ of the total potential respondents surveyed were using EC in their day-to-day business operations. This fact is of critical importance to researchers and practitioners alike when we think of the billions of dollars spent annually by organizations, vendors and governments on the development, implementation and use of EC technologies and approaches for business improvement and strategic advantage. Of course, further studies would need to be done to qualify this as a possible issue, however, responses (or lack of them) may indicate the relative unimportance of EC to SME's (in this case within the Swedish context).

The questionnaire instrument (relevance to each SME, interpretation of content, SME motivation to answer a questionnaire etc) may have also been a barrier to potential respondents, hence the low response rate. It must also be stressed that the data from this study represents only the most superficial indication of what these businesses deem to be important in EC uptake and use. It is envisaged that the research team will conduct indepth interviews with some of the respondent businesses in order to contextualise responses and obtain a greater insight into why these business feel that these factors are so important.

The respondent group in this study covered retail, industrial, service and financial sectors. $96 \%$ of the respondents had been in business for more than 2 years. $92 \%$ of respondents indicated that they had been using some form of IT for at least the last 2 years. Table 1 provides the overall responses for the major driving forces behind the adoption of EC. Some respondents did not complete the questionnaire fully. This was taken into account in the statistical analysis. 
Table 1

Factors which were the major driving forces behind the adoption of EC

\begin{tabular}{|c|c|c|c|c|c|}
\hline & $\begin{array}{c}\text { No } \\
\text { importance }\end{array}$ & $\begin{array}{c}\text { Little } \\
\text { importance }\end{array}$ & $\begin{array}{c}\text { Some } \\
\text { importance }\end{array}$ & $\begin{array}{c}\text { Very } \\
\text { important } \\
\end{array}$ & $\begin{array}{c}\text { Greatest } \\
\text { importance }\end{array}$ \\
\hline Customer demand & 48 & 25 & 20 & 19 & 6 \\
\hline $\begin{array}{l}\text { PRESSURE BY } \\
\text { COMPETITION }\end{array}$ & 36 & 20 & 32 & 19 & 9 \\
\hline PRESSURE BY SUPPLIERS & 57 & 23 & 19 & 13 & 3 \\
\hline REDUCED COST & 13 & 12 & 28 & 37 & 27 \\
\hline $\begin{array}{c}\text { IMPROVED CUSTOMER } \\
\text { SERVICES }\end{array}$ & 6 & 1 & 16 & 43 & 52 \\
\hline $\begin{array}{l}\text { IMPROVEMENT TO LEAD } \\
\text { TIME }\end{array}$ & 29 & 14 & 23 & 30 & 19 \\
\hline INCREASED SALES & 17 & 13 & 35 & 25 & 26 \\
\hline $\begin{array}{l}\text { IMPROVED INTERNAL } \\
\text { EFFICIENCY }\end{array}$ & 6 & 2 & 20 & 54 & 39 \\
\hline $\begin{array}{c}\text { DEVELOPMENT OF NEW } \\
\text { MARKETS }\end{array}$ & 18 & 15 & 21 & 33 & 30 \\
\hline $\begin{array}{c}\text { IMPROVED } \\
\text { COMPETITIVENESS }\end{array}$ & 13 & 5 & 18 & 41 & 39 \\
\hline IMPROVED MARKETING & 24 & 8 & 21 & 30 & 33 \\
\hline $\begin{array}{c}\text { GREATER CONTROL OF } \\
\text { BUSINESS }\end{array}$ & 25 & 16 & 28 & 29 & 19 \\
\hline $\begin{array}{c}\text { IMPROVED } \\
\text { RELATIONSHIPS WITH } \\
\text { BUSINESS PARTNERS }\end{array}$ & 16 & 11 & 32 & 39 & 19 \\
\hline
\end{tabular}

\section{ii) Analysis of Responses}

A series of chi-square tests were carried out to determine whether the major market focus was significantly associated with the rating of any of the driving forces or criteria behind EC adoption. The results indicate that the major market focus was not associated with any of the driving forces. However, the existence of a fully developed plan for EC and the size of the business were associated with the development of new markets as a driving force behind EC adoption (see Tables $3 \& 4$ ). There was also a clear association of size of SMEs of a larger size being more likely to have a plan (see Table 2). Previous studies (MacGregor \& Bunker (1996a), Bunker \& MacGregor (2000)) found that SME's in general were more likely to have an operational focus and therefore little strategic motivation for formal planning. Within the context of this study, as these SMEs grow larger they seem more likely to shift their focus to strategic management approaches like the production of formal EC plans. 
Table 2

Rating of the number of employees as a criteria for the adoption of EC

\begin{tabular}{|c|c|c|c|c|c|c|}
\hline & $\begin{array}{c}\text { Single } \\
\text { Employee } \\
\end{array}$ & $\begin{array}{c}<10 \\
\text { Employees } \\
\end{array}$ & $\begin{array}{c}10-19 \\
\text { Employees }\end{array}$ & $\begin{array}{c}20-49 \\
\text { Employees } \\
\end{array}$ & $\begin{array}{c}50-200 \\
\text { Employees }\end{array}$ & $\begin{array}{c}>200 \\
\text { Employees }\end{array}$ \\
\hline Fully developed plan & 10 & 53 & 24 & 22 & 18 & 5 \\
\hline No plan $* * *$ & 15 & 52 & 8 & 4 & 1 & 0 \\
\hline
\end{tabular}

$(\mathbf{p}<.001)$

Table 3

Rating of the importance of developing new markets as a criteria for the adoption of EC

\begin{tabular}{|l|ccccc|}
\cline { 2 - 6 } \multicolumn{1}{c|}{} & \multicolumn{4}{c|}{ (Developed plan versus no plan) } \\
\cline { 2 - 7 } \multicolumn{1}{c|}{} & $\begin{array}{c}\text { No } \\
\text { importance }\end{array}$ & $\begin{array}{c}\text { Little } \\
\text { importance }\end{array}$ & $\begin{array}{c}\text { Some } \\
\text { importance }\end{array}$ & $\begin{array}{c}\text { Very } \\
\text { important }\end{array}$ & $\begin{array}{c}\text { Greatest } \\
\text { importance }\end{array}$ \\
\hline Fully developed plan & 7 & 13 & 15 & 24 & 22 \\
No plan & 10 & 0 & 6 & 6 & 5 \\
\hline$(\mathbf{p}<.005)$ & \multicolumn{7}{c}{} \\
\hline
\end{tabular}

Table 4

Rating of the importance of developing new markets as a criteria for the adoption of EC

\begin{tabular}{|l|ccccc|}
\multicolumn{1}{c|}{} & \multicolumn{4}{c|}{ (Number of employees) } \\
\cline { 2 - 6 } No of employees & $\begin{array}{c}\text { No } \\
\text { importance }\end{array}$ & $\begin{array}{c}\text { Little } \\
\text { importance }\end{array}$ & $\begin{array}{c}\text { Some } \\
\text { importance }\end{array}$ & $\begin{array}{c}\text { Very } \\
\text { important }\end{array}$ & $\begin{array}{c}\text { Greatest } \\
\text { importance }\end{array}$ \\
\hline $\mathbf{0}$ & 4 & 1 & 0 & 3 & 1 \\
$\mathbf{1}-\mathbf{9}$ & 8 & 3 & 9 & 8 & 21 \\
$\mathbf{1 0}-\mathbf{1 9}$ & 1 & 1 & 6 & 8 & 5 \\
$\mathbf{2 0}-\mathbf{4 9}$ & 1 & 4 & 5 & 8 & 1 \\
$>\mathbf{5 0}$ & 4 & 6 & 1 & 6 & 2 \\
\hline $\mathbf{p}<\mathbf{0 0 1 )}$ & & & & & \\
\cline { 1 - 6 }
\end{tabular}

\section{DISCUSSION}

Before examining the data in detail, it is interesting to note that of the 260 respondents, only 118 (45.4\%) indicated that they are using EC in their day-to-day business activities. This will be the subject of a study to be produced by the authors.

A number of authors and studies (Wilder, 1999; Price Waterhouse Coopers, 1999; Violino, 2000b; Riemenschneider \& Mykytyn, 2000) have suggested that factors other than strict ROI are being used by SMEs as criteria to be considered for the adoption of EC. A closer examination of Table 1 would tend to support this, at least amongst the respondent group. While reduction of cost was seen as important as a criterion for the adoption of EC, by far the strongest reasons appear to be improvements to customer services, improvements to internal efficiency and improvements to organisational competitiveness. While these figures do not actually reject ROI, they suggest that for SMEs, ROI is only one of several factors that need to be taken into consideration when adopting EC.

The InformationWeek Research Global IT Strategies (2001) study found that organisations which are classified as export leaders are more likely to invest in leading edge IT (cited in Thyfault, 2001). According to this study, most export leaders invest in e-business which results in a higher percentage of their revenue coming from global sales. The results of the survey presented in this paper indicate, however, tha major business markets were not significantly associated with any of the driving forces behind EC adoption. Export SMEs in Sweden were no more likely to adopt EC than SMEs operating locally and nationally. Several reasons have been put forward by different authors for SMEs' lack of interest in exporting and international markets. Nielson and Morris (2001) suggest that, despite the opportunities afforded by EC, SMEs still face traditional problems including poor transport and distribution networks, inefficient customs procedures and barriers to market access in key export markets, such as high tariffs or restrictive trade practices. Shewmake and Sapp (2000) also list obstacles that SMEs may encounter, including language barriers, tariffs, diverse currencies and customs regulations. They state that "as a result of these problems, many companies have yet to move their e-business beyond their native shores" (ibid, 2000:30). Bennett's study (1997) shows that one of the reasons some 
organisations have not set up a Web site is because they do not perceive the Internet as making exporting any easier. Hamill and Gregory (1997) identified four different categories of export barriers including psychological, operational, organisational and product/market. It appears that these barriers remain obstacles to the internationalisation of SMEs despite the advent of EC. This can also be related to organisational size as a larger business is more likely than an SME to have available resources (specialist IT staff, dedicated budgets, multinational experience) to facilitate a global EC strategy.

Despite these results, an examination of Table 2 indicates that larger SMEs ( $>20$ employees) are more likely to have a fully developed EC plan (almost $100 \%$ of these organisations). This leads us to ask the question: is planning a natural function of size of a business? Once an SME increases in size and sees the need and necessity to plan, does the business have a different perspective of opportunity and the use of IT and EC due to its resource base increase and market intensity. Does this naturally give the larger SME access to more business opportunities (developing new markets) as a result?

An examination of Table 3 indicates that $57 \%$ of those who had developed a plan for EC adoption saw the development of new markets as being of extreme importance (categorised by respondents as being very important or of greatest importance) as a criterion for EC adoption, and only $8 \%$ saw no importance in the criterion. This reinforces the findings in Table 2. By comparison, of those respondents who had not developed a plan, $41 \%$ saw the driving force development of new markets as being of extreme importance (categorised by respondents as being very important or of greatest importance) as a criterion for EC adoption, while $37 \%$ saw no importance. Tetteh and Burn (2001) support the view that SMEs need to adopt a strategic outlook in their planning and management in order to adopt an e-business infrastructure, while Hamill (1997) highlights the need for export planning and adopting a strategic approach to new markets. It is interesting to note that the development of an EC plan gave those SMEs an insight into the importance of new markets, however the responses also indicate that these businesses did not link EC directly to the development of new markets. This may indicate the importance of planning rather than technology in creating new (perceived) business opportunities for these businesses. This is an especially critical finding given the more operational orientation of most SME's supported by previous studies (MacGregor \& Bunker (1996a), Bunker \& MacGregor (2000).

Finally, Table 4 indicates that smaller sized SMEs ( 2 to 20 employees) placed a higher level of importance on the use of EC to develop new markets than those organisations which consisted of the sole entrepreneur and those whose staffing level was greater than 20 . In fact, $40 \%$ of these small sized SMEs indicated they saw the development of new markets as being of extreme importance (categorised by respondents as being very important or of greatest importance) as a criterion for EC adoption. As we can see by the previous tables, however, the likelihood of SMEs of this size having a formal EC plan (and thus an understanding of the market opportunities) is only at a level of $50 \%$. This represents a potential barrier to the effective uptake and use of IT and EC by these smaller SMEs.

\section{CONCLUSION}

This research has sought to identify factors that influence the adoption of EC by SMEs. Improvement in customer services, improvement to internal efficiency (small and larger SMEs) and improvement to organisational competitiveness (larger SME) were rated as the most important criteria for the adoption of EC in the organisation. Clearly, while ROI remains an important consideration, the 'all pervasiveness' of EC within the organisation has meant that ROI is only one of many factors needing to be considered.

The globalisation and internationalisation of markets presents a new challenge to SMEs (Raymond, 2001). Meeting this challenge has been made easier by the advent of EC which has opened up new opportunities and new markets for, not only large, but also small and medium organisations, including those from developing countries (Nielson \& Morris, 2001). The research presented here has indicated that the adoption of EC by SMEs was not associated with their major market focus, but may be better correlated to the size of the business (in terms of employee numbers). It appears that export SMEs still face similar challenges to those that existed before the advent of EC. Raymond (2001) and Quelch and Klein (1996) argue that SMEs need support from government organisations in developing marketing strategies that are appropriate in a global business environment. Nielson and Morris (2001) also suggest that in order to increase cross-border trade, much has to be done by way of international regulatory cooperation, while Hamill (1997) states that internet training should be a top government priority. It would appear that many of these issues become a greater reality (and therefore more critical) as the size of the SME increases.

As SME's grow in size perhaps they will identify new markets and exports through more formal planning mechanisms, rather than governments and IT vendors attempting to create these market and export opportunities in an artificial manner.

Recent studies have shown that for the adoption of EC to be successful, there is a need to fully plan its acquisition and use. This study supports this notion by showing that the existence of an organisational wide plan is associated directly with the importance rating of developing new markets as a criterion for EC adoption. This 
is further correlated with the size of the SME (in terms of employee numbers) that appears to have some bearing on the importance placed on the development of new markets when decisions are being made.

Clearly, additional research is required to refine and understand the issues identified in this and other studies, however, it would appear that EC adoption is just as prevalent among local and national SMEs, as it is among SMEs that export.

\section{ACKNOWLEDGEMENTS}

The authors would like to express their appreciation to S Berggren and A Stjärnkvist for their help in distributing and collating the questionnaires.

\section{REFERENCES}

ALAVI, M. (1984) An Assessment of the Prototyping Approach to Information Systems Development, Communications of the ACM, 27(6), 556- 563

AMOAKO-GYAMPAH, K. \& K.B. WHITE (1993) User Involvement and Satisfaction: An exploratory contingency model, Information \& Management, 25(1), 1 - 10

BARNETT, R.R. and J.R. MACKNESS (1983) An Action Research Study of Small Firm Management, Journal of Applied Systems, 10, 63 - 83

BAROUDI, J.J., M.H. OLSON and B. IVES (1986) An empirical study of the impact of user involvement on system usage and information satisfaction, Communications of the ACM, 29(3), 232 - 238

BENNETT, R. (1997) Export marketing and the Internet: Experiences of Web site use and perceptions of export barriers among UK businesses, International Marketing Review, 14(5), 324 - 344

BERGERON, F., S. RIVARD and L. De SERRE (1990) Investigating the Support Role of the Information Centre, MIS Quarterly, 14(3), 247 - 260

BRIGHAM, E.F. and K.V. SMITH (1967) The Cost of Capital to the Small Firm, The Engineering Economist, $13(1), 1-26$

BRYNJOLFSSON, E. and L.M. HITT (1998) Beyond the Productivity Paradox, Communications of the ACM, 41(8), 49 - 55

BUNKER, D.J. \& R.C. MacGREGOR (2000) Successful Generation of Information Technology (IT) Requirements for Small/Medium Enterprises (SME's) - Cases from Regional Australia. In Proceedings of SMEs in a Global Economy, 72 - 84, Wollongong, Australia

BURTON, F., Y. CHEN and V. GROVER (1993) An Application of Expectancy Theory for Assessing User Motivation to Utilise an Expert System, Journal of Management Information Systems, 9(3), 183 - 198

CAMERON, P. (2000) Measuring Up, CMA Management, 74(2), 26 - 28

COCHRAN, A.B. (1981) Small Business Mortality Rates: A Review of the Literature, Journal of Small Business Management, 19(4), 50 - 59

DITSA, G.E.M. (1994) Measures of User Acceptance of Information Systems, Master of Commerce Dissertation, Department of Information Systems, University of Wollongong

DUGAN, S. (1999) The Revenue Factors: Strategies for Maximizing E-Commerce Success, Infoworld, 21(40), $70-72$

ELLSWORTH, J.H. and M.V. ELLSWORTH (1997) Marketing on the Internet, John Wiley \& Sons, New York

EVANS, C. (2001) An e-strategy for online e-business, Information Systems Management, 18, 8 - 21

FINK, D. and F. TJARKA (1994) Information Systems Contribution to Business Performance: A Study of Information Systems Executives' Attitudes, Australian Journal of Information Systems, 2(1), 29 - 38

FULLER, T. (2000) The Small Business Guide to the Internet: A Practical Approach to Going Online, International Small Business Journal, 19(1), 105 - 107

GINZBERG, M.J. (1978) Steps towards more effective implementation of MS and MIS, Interfaces, 8(3), 57 63

GINZBERG, M.J. (1982) Key Recurrent Issues in MIS Implementation Program, MIS Quarterly, 5(2), 47 - 59

HAMILL, J. (1997) The Internet and international marketing, International Marketing Review, 14(5), 300 323

HAMILL, J. and K. GREGORY (1997) Internet marketing in the internationalisation of UK SMEs, Journal of Marketing Management, 13(1-3), 9 - 28

HLAVA, M.M.K. (1999) Expanding partnerships for Small-and Medium-Sized Enterprises (SMEs) Needed: The Right Kind of Support, Bulletin of the American Society of Information Science, 25(5), 7 - 9

IVES B., M.H. OLSEN and J.J. BAROUDI (1983) The Measurement of User Information Satisfaction, Communications of the ACM, 26(10), 785 - 793 
JARVENPAA, S. \& B. IVES (1991) Executive Involvement and Participation in the Management of Information Technology, MIS Quarterly, 15(2), 205 - 225

KENDALL, K.E. (2000) E-Commerce Aesthetics: E-Commerce for E-Commerce' Sake, Information Resources Management Journal, 13(3), 3 - 4

KLATT, L.A. (1973) Small Business Management: Essentials of Entrepreneurship, Wadsworth, CA

KOLLMAN, T. (1998) Marketing for Electronic Market Places - The Relevance of Two 'Critical Points of Success, Electronic Markets, 8(3), 36 - 39

KORCHAK, R. and R. RODMAN (2001) eBusiness Adoption Among US Small Manufacturers and the Role of Manufacturing Extension, Economic Development Review, 17(3), 20 - 25

KULJIS, J., R. MACREDIE and R.J. PAUL (1998) Information Gathering Problems in Multinational Banking, Journal of Strategic Information Systems, 7(3), $233-245$

LEWIS, D. (2000) Some Retailers De-Emphasize Web Payback, InternetWeek, 834, 94

McDONIEL, P.L., J. PALKO and T.P. CRONAN (1993) Information Systems Development: Issues Affecting Success, Journal of Computer Information Systems, 34(1), 50 - 62

MacGREGOR, R.C. \& R.S. COCKS (1995) Computer Usage and Satisfaction in the Australian Veterinary Industry, Australian Veterinary Practitioner, 25(1), 32 - 39

MacGREGOR, R.C., D.J. BUNKER, J.K. PIERSON and K.A. FORCHT (1995) Levels of Satisfaction with Pre and Post Installation Vendor Contact: Their Effect on Small Business and College/University Technology Course Requirements, Education Foundation of the Data Processing Management Association, 78 84

MacGREGOR, R.C. \& D. J. BUNKER (1996a) The Effect of Priorities Introduced During Computer Acquisition on Continuing Success with IT in Small Business Environments. In Proceedings of the Information_Resource Management Association International Conference, 271 - 277, Washington D.C.

MacGREGOR, R.C. \& D.J. BUNKER (1996b) The Effect of Setting Performance Criteria When Acquiring Computer Technology on the Perceptions of Ongoing Success with Information Technology in the Small Business Environment. In Proceedings of the 25th Annual Meeting of the Western Decision Sciences Institute, $277-279$

MALOFF, J. (1995) The Virtual Corporation, Internet World, 5, 46 - 50

MARKLAND, R.E. (1974) The Role of the Computer in Small Business Management, Journal of Small Business Management, 12(1), $21-26$

MIRCHANDANI, D.A and J. MOTWANI (2001) Understanding Small Business Electronic Commerce Adoption: An Empirical Analysis, Journal of Computer Information Systems, 41(3), 70 - 73

MOOZAKIS, C. and D. LEWIS (2000) Enterprises Tailor ROI To E-Business, InternetWeek, 842, 90

NATIONAL SMALL BUSINESS UNITED and ARTHUR ANDERSEN (1998) Annual Survey of Small and Mid-Sized Business, NSBU

NATIONAL SMALL BUSINESS UNITED and ARTHUR ANDERSEN (1997) Annual Survey of Small and Mid-Sized Business, NSBU

NATIONAL SMALL BUSINESS UNITED and ARTHUR ANDERSEN (1996) Annual Survey of Small and Mid-Sized Business, NSBU

NIELSON, J. \& R. MORRIS (2001) E-commerce and trade: Resolving dilemmas, Organisation for Economic Cooperation and Development. The OECD Observer, No 224, 37 - 39

POON, S. (2000) Business environment and internet commerce benefit - a small business perspective, European Journal of Information Systems, 9, 72 - 81

POON, S. and P.M.C. SWATMAN (1997) Small business use of the Internet: Findings from Australian case studies, International Marketing Review, 14(5), 385 - 402

PORTER, M. (2001) Strategy and the Internet, Harvard Business Review, March, 63 - 78

PRICE WATERHOUSE COOPERS (1999) SME Electronic Commerce Study Final Report, 37pp

QUELCH, J.A. and L.R. KLEIN (1996) The Internet and international marketing, Sloan Management Review, $37(3), 60-75$

QUINN, J. (2000) Untenable ROI spreads e-panic, Computing Canada, 26(6), 15

RAISCH, W.D. (2001) The eMarketplace: Strategies for Success in B2B, McGraw Hill, New York

RAJKUMAR, T.M. (2001) E-Procurement: Business and Technical Issues, Information Systems Management, 18, $52-60$

RAYMOND, L. (2001) Determinants of Web site implementation in small business, Internet Research: Electronic Networking Applications and Policy, 11(5), 411 - 422

RIEMENSCHNEIDER, C.K. and P.P.jr MYKYTYN (2000) What Small Business Executives have Learned About Managing Information Technology, Information \& Management, 37, 257 - 267

REYNOLDS, W., W. SAVAGE and A. WILLIAMS (1994) Your own business: A practical guide to success, ITP 
ROBEY, D. (1987) Implementation and the Organisational Impact of Information Systems, Interface, $17(3), 72$ $-84$

ROTCH, W. (1987) Management of small enterprises: cases and readings, University of Virginia Press

SCHULTZ, R.L., M. J. GINZBERG and H.C.jr LUCAS (1984) A Structural Model of Implementation. In Schultz, R.L. and M.J. Ginzberg (eds) Application of Management Science, JAI Press, Greenwich, 55 87

SHEWMAKE, B. and G. SAPP (2000) Bringing down the international barriers, InfoWorld, 22(18), 30

SZAJNA, B. and R. SCAMELL (1993) The Effects of Information Systems User Expectations on their Performance and Perceptions, MIS Quarterly, 17(4), 493 - 614

TETTEH, E. and J. BURN (2001) Global strategies for SMe-business: applying the SMALL framework, Logistics Information Management, 14(1/2), 171 - 180

TAIT, P. and I. VESSEY (1988) The Effect of User Involvement on System Success: A Contingency Approach, MIS Quarterly, 12(1), $91-108$

THONG, J.Y.L (1999) An Integrated Model of Information Systems Adoption in Small Businesses, Journal of Management Information Systems, 15(4), 187 - 214

THYFAULT, M.E. (2001) Heavy exporters spend big on leading-edge IT, Informationweek, 834, 54

TURBAN, E., J. LEE, D. KING and H. CHUNG (2000) Electronic Commerce: A Managerial Perspective, Prentice Hall, New York

VIOLINO, B. (2000a) IT Excellence 500, Internetweek, 754, 48 - 62

VIOLINO, B. (2000b) Payback Time For E-Business, Internetweek, Special Issue 811, 1

WALKER, E.W. (1975) Investment and Capital Structure Decision Making in Small Business. In Walker, E.W. (ed) The Dynamic Small Firm: Selected Readings, Austin Press, Texas

WILDER, C. (1999) ROI: E-business Strategic Investment, Informationweek, 735, 48 - 56

YAP, C.S., C.P.P. SOH and K.S. RAMAN (1992) Information System Success Factors in Small Business, OMEGA International Journal of Management Science, 20(5-6), 597 - 609 